\title{
LA CONFIGURACIÓN DEL PATRIMONIO ARQUEOLÓGICO COMO BIEN DE DOMINIO PÚBLICO EN EL ORDENAMIENTO JURÍDICO ESPAÑOL
}

\author{
THE CONFIGURATION OF THE ARCHAEOLOGICAL HERITAGE AS \\ PUBLIC PROPERTY IN THE SPANISH LEGAL SYSTEM
}

\author{
FERNANDO GABARDÓN DE LA BANDA*
}

\begin{abstract}
Resumen: A diferencia del resto de los bienes culturales, desde la promulgación de la Ley de 1985 del Patrimonio Cultural, el Patrimonio Arqueológico se ha considerado como un bien de dominio público, lo que ha provocado un amplio debate doctrinal en el ámbito español. En este trabajo he intentado analizar las posibles raíces históricas que desde la época borbónica hasta la promulgación de la ley de 1911, en plena etapa liberal, fue adquiriendo un tratamiento legal específico, al centrase el eje de su ordenamiento específico en la adquisición de la propiedad de los bienes arqueológicos encontrados en los hallazgos y exacciones que paulatinamente se fueron desarrollando en esta fase. Palabras clave: Dominio público; bien arqueológico; propiedad monumental
\end{abstract}

\section{A MODO DE INTRODUCCIÓN. EL PATRIMONIO ARQUEOLÓGICO COMO BIEN DE DOMINIO PÚBLICO EN EL SISTEMA NORMATIVO ESPAÑOL.}

No cabe duda de que desde la génesis del sistema normativo tutelar del Patrimonio Cultural en España en el periodo borbónico, el patrimonio arqueológico siempre ha contado con una referencia específica, al delimitarle una singular protección que lo distinguiría del resto de los bienes culturales en el ámbito del ordenamiento español. Su peculiaridad radica en el hecho de

\footnotetext{
* Universidad de Sevilla-Universidad San Pablo CEU
}

\begin{abstract}
As opposed to the rest of cultural goods, since the 1985 Act on Cultural Heritage was passed, the archaeological heritage has been considered as public domain, triggering an important debate in the Spanish cultural and social sphere. In this paper, I have tried to analize the possible historical roots which, from the "Borbonic" era until the 1911 Act was passed, acquired specific legal treatment, as the core of the legal system focused on the acquisition of archaeological goods discovered during the research and excavations that were carried out in that era.
\end{abstract}

Key words: Concepts: public domain; archaeological goods; monumental property

considerar a los bienes integrantes del Patrimonio Arqueológico como Bienes de Dominio Público, perfil jurídico que no lo vamos a encontrar en el resto de los bienes integrantes del Patrimonio Cultural. Sería con la promulgación de la Ley de 1985, en su artículo 44.1., donde se insertaría definitivamente el carácter dominal de los bienes arqueológicos: "son bienes de dominio público todos los objetos y restos materiales que posean los valores que son propios del Patrimonio Histórico Español y sean descubiertos como consecuencias de excavaciones, remociones de tierra y obras de cualquier índole o por azar, entendiendo por bienes arqueológicos aquellos susceptibles de ser estudiados con metodología arqueológica" (art.40.1). Son los hallazgos arqueológicos los que van a ser calificados por 
consiguiente como bienes de dominio público, por lo que es el hecho del descubrimiento el que delimita el surgimiento de la entidad jurídica.

La ley de 1985 adoptaría un sistema de adquisición automática de los hallazgos interesantes y la reducción del juego de los principios de ocupación y accesión a la mitad del valor de lo hallado, quedando la otra mitad del Estado sin contrapartida. Se trata de una solución intermedia entre la plena nacionalización y el pleno reconocimiento en valor de los derechos de los particulares. Nótese que los hallazgos que el artículo $44.1^{\circ}$ atribuye al Estado se declaren bienes de dominio público y no, por tanto, al parecer, bienes patrimoniales del Estado. En realidad, hasta ahora, las adquisiciones de hallazgos de interés histórico-artístico por el Estado suponían para éste la titularidad como bienes patrimoniales de lo adquirido, y no se ve por qué el legislador ha declarado dichos bienes como de dominio público, lo que acaso era en realidad innecesario (Moreu 1995).

Una amplia discusión doctrinal ha ido surgiendo en torno a la naturaleza jurídica del Patrimonio Arqueológico como bienes de dominio público. J. Barcelona Llop (2000: 137) apunta que "si el dominio público es un producto del ordenamiento jurídico el artículo 44 de la Ley 16/1985 crea el dominio público arqueológico. Nótese que no es que algunos bienes arqueológicos sean dominales por una u otra razón, sino que los son a los que el precepto se refiere (...) por primera vez en nuestra historia jurídica, los bienes arqueológicos se dicen de dominio público (...)”. A. Roma Valdés (2008: 5). delimita el carácter público de los bienes arqueológicos descubiertos en el ordenamiento español: "se trata de un dominio público por naturaleza, esto es que, los bienes integrantes de cualquier yacimiento arqueológico (esté o no en excavación) son merecedores de esta protección, sin necesidad de un acto de ocupación, ni de declaración previa por parte de la Administración. Así, el subsuelo nacional, en la medida que encierre bienes susceptibles de aportar un conocimiento de nuestro pasado, contiene objetos que pertenecerán al dominio público una vez sean descubiertos. La afectación propia de todo dominio público se verá caracterizada por aquellos bienes que contengan información del pasado. Sobre esta base, los bienes arqueológicos presentan unas características con las minas, también de dominio público, en la medida en que es su propia naturaleza la que determina la configuración demanial. A modo de diferencia, las minas son susceptibles de aprovechamiento particular previa concesión, mientras que en el patrimonio arqueológico no se prevé la apropiación de los productos por los particulares, sino únicamente la utilización por parte de la Administración
J.M. Alegre Ávila reiteraría el carácter demanial de los bienes arqueológicos en su análisis jurídico del Patrimonio Cultural, y justifica su identificación como dominio público estatal. Finalmente, podríamos recoger la tesis de M$^{\mathrm{a}}$. Á. Querol y B. Martínez Díaz por la que afirman que el Patrimonio Arqueológico potencial -aquel que ha de descubrirse- tanto en sus elementos muebles como inmuebles, sea de dominio público, impidiéndose así su conversión en propiedad privada o en objeto de comercio.

¿Cuál es la razón histórica de considerar el Patrimonio Arqueológico como un Bien de Dominio Público en nuestra tradición legislativa, dejando excluidos a los demás bienes del Patrimonio Cultural? La construcción del Derecho del Patrimonio Cultural en la etapa del preconstitucionalismo democrático se articularía por el régimen de la propiedad, por lo que el sistema tutelar de los bienes a proteger dependían de quien fuera su propietario. La concepción del Estado-propietario, la única fórmula de viabilidad de superar el derecho absoluto de la propiedad privada y la amplia vulnerabilidad que ofrecían los bienes arqueológicos, no solamente por su acceso, al encontrarse en dominios privados, sino por la propia ignorancia de su existencia, hizo que el legislador optara por esta modalidad patrimonial. Este matiz lo diferenciaría del resto del Patrimonio Cultural, y se convertiría en el verdadero triunfo de la función social de la propiedad monumental al ir quebrando paulatinamente la idea de que los bienes histórico-artísticos estaban adheridos al derecho de goce y disposición de sus exclusivos propietarios, siendo excluidos de su interés público.

Incluso en la actualidad, cuando se ha ido configurando la nueva concepción del bien cultural como aquellos bienes cuyo valor intrínseco iban más allá de su propio régimen de propiedad, el legislador español constitucionalista le ha dotado curiosamente de este rasgo, por lo que nuevamente lo ha diferenciado del resto de los bienes culturales que forman parte del $\mathrm{Pa}$ trimonio Cultural Español, como podemos apreciar en el artículo 46 de la Constitución.

La construcción jurídica del Patrimonio Arqueológico se iría definiendo, por consiguiente, como el resto de los bienes culturales, en base al régimen de la propiedad que se plasmaba en dos hechos primordiales: la excavación y el hallazgo arqueológico, que, aunque desde el punto de vista de la investigación científica permanecían diluidos en este periodo, no por ello no se practicaba en innumerables ocasiones. Tres sujetos primordiales intervendrían en todo hallazgo arqueológico: el Estado, cuya posición iría ganando terreno en virtud de la adquisición de prerrogativas administrativas 
de intervención; el propietario del fundo donde se encontraba el bien arqueológico, quien defendía la posesión de éste como cualquier otro bien patrimonial que se encontrase en su terreno, aunque fuera en este caso en el subsuelo; y el descubridor, que siempre optaría bien por una recompensa metálica o por la adquisición de la propiedad. En el múltiple juego de relaciones que se podían dar en estos casos fue configurándose un sistema normativo en el que el Estado fue considerando la adquisición en propiedad de estos bienes desde una mera tutela en la etapa borbónica, pasando por las distintas disposiciones del régimen liberal, con el valor absoluto de la propiedad privada y su consiguiente resquebrajación.

No fue hasta la llegada del periodo liberal en España cuando se dieron los primeros pasos a la hora de calificar como dominio público a los bienes arqueológicos. Los continuos expolios arqueológicos, la identificación de estos bienes como parte de la identidad nacional o los auspicios de un gran número de instancias privadas de carácter cultural y de grandes arqueólogos venidos del extranjero, instó al Estado a dar una respuesta tutelar, promulgando un amplio número de normas cuya orientación culminó con la delimitación del Bien Arqueológico como Dominio Público. Sin embargo, una cuestión crucial limitó su concepción pública: la configuración del derecho de la propiedad privada como derecho absoluto, lo que produjo un conflicto de intereses por el que el Estado quedó limitado a la hora de tutelar los bienes situados en la esfera privada. De esta manera el Bien Arqueológico se insertaba, como el resto de los bienes pertenecientes al Patrimonio Cultural, en un sistema tutelar fundamentado en el régimen de la propiedad, por lo que se convertía en un derecho inherente al dueño en cuestión, o al descubridor en su caso.

Sin embargo, el Estado Liberal irá quebrando la concepción patrimonialista a lo largo del siglo XIX al ir cambiando su calificación jurídica en función de la evolución que experimenta la legislación hasta dotarlo de un carácter demanial. Sin ninguna duda podemos afirmar que se trata de un cambio de escenario jurídico que no lo encontramos en el resto de los bienes que configuran el Patrimonio Monumental. El papel predominante del Estado en la tutela jurídica que va a ir adquiriendo a lo largo de este proceso va a ser un hecho trascendental en la historia jurídica del Patrimonio Monumental Español, ya que es cuando podemos afirmar que se va ir implantando la idea de una función social de la propiedad del bien arqueológico, aunque se tutela más bien por el valor intrínseco que representa -la exaltación de la identidad nacional- que más allá de un simple derecho inherente al propietario. El descubridor no tiene por qué quedarse con el bien descubierto sino que va a ser obligado a cedérselo al Estado a cambio de una indemnización. El dueño del fundo privado, en el caso de que no se descubra en un terreno público, va ir perdiendo el derecho absoluto de la propiedad privada del bien descubierto en favor del Estado.

\section{EL PATRIMONIO ARQUEOLÓGICO COMO DOMINIO DE LA MONARQUÍA EN LA ETAPA BORBÓNICA}

Durante la etapa del Despotismo Ilustrado, el Patrimonio Arqueológico fue adquiriendo una considerable tutela a raíz de los hallazgos de antigüedades clásicas, en un momento en que el mundo grecorromano constituía un fundamento político de las grandezas de la institución monárquica. La cuestión primordial que se nos plantea en este momento es la referente a la tutela patrimonial, ya que las excavaciones en la mayoría de los casos no formaban parte de una planificación sistemática de los poderes públicos, ya que los particulares, anticuarios y amantes del mundo de las antigüedades eran los que se dedicaban a rescatar los bienes del pasado clásico.

Los problemas de la tutela patrimonial no serían tal si a los bienes históricos-artísticos no se les hubiera comenzado a dotar de un valor jurídico, por lo que el Estado debía de intervenir en aras de su conservación. El conflicto de intereses producidos entre las pretensiones del descubridor de adquirir el bien para su colección particular y el propio Estado va a ir subsumiendo una situación preliminar en esta etapa que culminará, como ya hemos apuntado en la consideración de dominio público de los bienes arqueológicos en el periodo actual. La autorización regia como símbolo del Estado para realizar excavaciones arqueológicas durante los años del Despotismo Ilustrado se convierte en un verdadero antecedente del procedimiento administrativo de legislaciones posteriores.

En las excavaciones de Pompeya y Herculano podemos vislumbrar una realidad jurídica que se va repitiendo en este periodo: la apertura hacia una concepción pública del dominio de un espacio arqueológico recién descubierto en un fundo privado (en este caso real) aunque tutelado por la propia Corona. Centrémonos en los hechos históricos. El descubrimiento de estas ciudades vesubianas desencadenó una verdadera revolución en el campo de los descubrimientos del mundo clásico. Aunque las excavaciones ya habían comenzado parcialmente unos años antes, fue con la llegada de Carlos al trono napolitano cuando empezaría a adquirir 
un verdadero auge. Así, desde 1738 comenzaría un proyecto auspiciado por Carlos III, aún rey de Nápoles, y que continuaría después de su marcha para acceder a la Corona española en 1759. No se trataba de unos descubrimientos aislados sino de un verdadero proyecto de sacar a la luz los restos de tres ciudades romanas que habían sido sepultadas por la erupción del Vesubio en el año 79 d.C. Al mismo tiempo fue surgiendo una peregrinación cultural de eruditos y anticuarios que querían admirar in situ los hallazgos, en unos años de auténtica veneración por lo clásico.

Dos hechos trascendentales surgieron en el ámbito de la Protección Monumental: la sistematización de la excavación arqueológica, que fue adquiriendo una identidad propia, y la configuración pública de la excavación sin perder el patrocinio real. Aunque las excavaciones no estuvieron exentas de polémicas, no cabe duda de que se fue generando una cierta organización administrativa, diferente a otras que se habían realizado hasta ese momento bajo la dirección real, que actuaba como patrocinador, pero a diferencia de los particulares, lo hará como símbolo del Estado, ajeno a sus propios intereses. Como señala J. Salas (1999: 165), el monarca consideró, en un indudable rasgo de modernidad, que sus amadas antigüedades no le pertenecían a él sino al reino "(...) Las excavaciones vinieron a hacer de Carlos el propietario de una enorme colección de pinturas que había que conservar, ordenar y disponer. Naturalmente, estaba fuera de lugar la idea de conservarlas en sus lugares de hallazgo, aún inaccesibles y con frecuencia posteriormente recubiertos. Para albergarlas, así como el resto de los objetos hallados, se habilitó en la villa de Carlos en Portici un museo (...) Aunque la autorización real para la visita no era excesivamente difícil de conseguir, no se trataba aún de un museo público en el pleno sentido de la palabra (...) representaba un indudable avance con respecto a los cabinets estrictamente privados de otras casas reales. El monarca no consideraba estas pinturas como propiedad personal suya - de hecho, no llevó a España ninguna-, pero se reservaba la autorización para visitar el museo, visita que adquiría así el carácter de una muestra del favor regio y no de un derecho de toda la comunidad intelectual". Las pinturas y demás objetos descubiertos pasarían a propiedad real, pero el futuro rey de España no los consideraba como una propiedad personal, sino que formaría parte de la Corona napolitana, hecho que le desligaba de las políticas que habían seguido otros monarcas coetáneos.

Sin embargo, no se puede considerar que estemos ya ante un verdadero museo público, ya que las piezas encontradas quedaban bajo la tutela del monarca.
No podemos obviar la existencia de un coleccionismo privado de antigüedades clásicas, alejado de la iniciativa real, practicado por un gran número de ilustrados. Amores, Fernández Lacomba y Beltrán (2008: 42) han realizado un interesante esbozo del coleccionismo de antigüedades en Andalucía desde el siglo XVI al XVIII en el que muestran los perfiles sociológicos existentes y los intereses diversos a la hora de acometer esta actividad [sobre el caso andaluz, J Salas (2004)].

La promulgación de la Real Cédula del 6 de junio de 1803 fue la primera referencia jurídica del derecho patrimonial histórico-artístico español, al definirse por primera vez lo que se entendía por Monumentos Antiguos, primera denominación en la literatura jurídica del bien a proteger. Siguiendo a Maier (2003: 59), fue la primera medida legislativa promulgada en España y en Europa relativa a la conservación del Patrimonio Arqueológico. Conocemos las vicisitudes de la elaboración del proyecto por el estudio que Maier ha realizado a raíz del II centenario de su promulgación. Urquijo, primer secretario de Estado, envió un oficio a Antonio Capmany para que la Academia propusiera un proyecto definiendo cuáles eran las medidas que había que adoptar para la salvaguarda del legado histórico digno de ser protegido. La respuesta llegaría pronto, pues el 19 de noviembre de 1801 la Academia envió al entonces Secretario de Estado, Pedro Cevallos Guerra (1764-1840), un informe preliminar en el que se exponía la definición de los distintos restos de antigüedades que han de someterse a protección y el modelo de protección. El primer aspecto que se pedía era precisamente la tutela administrativa del Patrimonio Monumental al solicitar la Academia la inspección de todas las antigüedades que se hallasen en el Reino, para lo cual las autoridades locales tendrían que colaborar a tal efecto en el momento en que se descubriera alguna pieza digna de consideración.

Sin embargo, ya se vislumbraba el reconocimiento del derecho de los particulares sobre el bien descubierto:

$\left.1^{\circ}\right)$ El descubrimiento ha sido por lo general efecto de la causalidad por que son pocos los que se exponen a los gastos de una escavacion para encontrar antigüedades, y en este caso debe el descubridor hacerse propio el monumento que descubre a menos de ser este de un gran tamaño o que necesite especial protección del Gov.

$2^{\circ}$ ) La explicación de las antigüedades que se descubran no puede ser privativa de nadie, sino común a todos los que sepan explicarla, y así la Academia no pretende arrogarse este privilegio sino uno de los muchos q. concurran con las luces y conocimientos de sus Individuos a la explicación de monumento descubierto. 
$3^{\circ}$ ) Se estimularán los hallazgos arqueológicos con una recompensa gratificación o precio que se aplique al verdadero descubridor a fin de extimular a otros en este género de industria antiquaria que conviene propagar en la Nación. Frente a la concepción privada, se va a ir abriendo paso la idea de una utilidad pública en la conservación del Patrimonio Monumental bajo el patrocinio del Monarca: En esta sucinta y general idea que acaba de extender y tiene el honor de dirigir a V.E. la Academia, cree estar haber manifestado sus vivos deseos de contribuir por su parte al fomento de este nuevo ramo de ilustración política pública cuya importante empresa espera se sirba V.E. patrocinar con su poderoso influxo al beneficio animo de S.M. siempre propenso a sostener todos los objetos de utilidad y lustre nacional. De esta manera el Monarca se convertía, siguiendo los ideales de la Ilustración, en el verdadero promotor de la conservación del legado patrimonial en beneficio del pueblo.

Un interesante ejemplo de la aplicación de la Real Cédula de 1803 sería el descubrimiento de las monedas de plata del período califal, encontradas en un fundo privado, donde se plantea el problema crucial de la adquisición de la propiedad de los bienes materiales encontrados. En el Informe de la Real Academia consta que D. Francisco Beltrán de Guevara, secretario del Cabildo de la Santa Madre Iglesia Catedral de esta ciu$\mathrm{dad}$, que habiendo proyectado ensanchar una casa de campo que tiene en heredad propia (...) principió las obras y en unas de las zanjas que se abrieron para sacar el cimiento se halló un tarro de barro que contenía porción de monedas o medallas de plata con caracteres arábigos; de cuya intención dio cuenta al Juzgado de esta intendencia donde se entregó las monedas cumpliendo lo prevenido en la Real Orden de 6 de julio de 1803, a través del Intendente, Don Nicolás Díaz. El legítimo propietario, y al mismo tiempo descubridor en este caso, el aludido Francisco Beltrán, enviaría un oficio el 31 de julio para que se le devolviesen las piezas o le pagaran la cuantía correspondiente, tal como aparece establecido en la Real Cédula de 1803. En una minuta de oficio fechada el 2 de septiembre de 1806, la Real Academia de la Historia comunicaría la proposición de compra una vez analizadas dichas piezas, por lo que se le remitiría el dinero por medio del Intendente: y me encarga se lo manifieste a V. y le proponga su compra, siempre que sea solo al peso, por ser comunes y no merecer otra estimación. Si conviniese a V. este partido, se le remitirá el dinero por medio de la persona a que se entreguen las demás para devolverlas al Intendente de cuyas manos podrá recogerlas. El 13 de octubre de 1806 serían devueltas por acuerdo de la Real Academia de la Historia las monedas de plata árabes que me remitió el 31 de julio próximo con el Ordinario de esa ciudad, Nicolás Díaz, quien las conduce, porte pagado, para que las haga V. entrega a su dueño D. Francisco Beltrán de Guevara, a excepción de doce que (...) se han separado para el museo de la misma Academia.

De la lectura de estos Informes de la Real Academia de la Historia podríamos deducir varios hechos:

$1^{\circ}$ ) El Estado, personalizado en la Monarquía, tendría potestad para adquirir la propiedad de cualquier pieza de antigüedad, a cambio de indemnizar a su propietario, que podía ser como en este caso incluso su descubridor.

$2^{\circ}$ ) El dueño del fundo donde se habían encontrado las piezas arqueológicas tendría siempre el derecho de reclamarlas, o bien ser indemnizado.

$3^{\circ}$ ) Sería la Real Academia de la Historia la encargada de decidir si estas piezas eran dignas de ser adquiridas por el Estado.

Sin embargo, en otros casos los bienes arqueológicos eran devueltos a sus legítimos propietarios, como fue el caso de los hallazgos ocurridos en el Pozo de la Sal, concretamente varias tumbas romanas. Nuevamente la cuestión de la propiedad del bien encontrado en un fundo privado se convertía en objeto de discrepancia. $Y$ es que a raíz del descubrimiento fortuito del labrador, y con la intención de ser vendidas para poder trasladarlas a Roma por un monje, el Alcalde del lugar, D. Pedro Pablo Echevarría suspendería las excavaciones. En el Informe realizado por la Real Academia de la Historia, se recordaría el artículo $2^{\circ}$ de la Instrucción, en la que se establecería que serán dueños de todos los monumentos descubiertos los que lo hallasen con sus heredades y casas o lo descubran a su costa y por su industria, con sola la carga de dar parte y noticia circunstanciada a la Academia por medio de su secretario. El 23 de julio de 1806, la Real Academia de la Historia dispondría la devolución de los objetos encontrados a su legítimo dueño, por lo que ha acordado que proceda a entregarlos a las personas que le corresponde su propiedad, con la condición de que no se extraigan fuera del Reino, como su S.M. tiene mandado, y asimismo que en adelante cuide $\mathrm{V}$ de dar parte al mismo Real Cuerpo de cualquiera otras antigüedades que se hallen en las excavaciones y se ejecuten, remitiendo, si hubiese proposición, dibujo de todo.

Como apunta Maier (2003: 32), el Informe de la Academia de la Historia se convertiría en un claro testimonio del equilibrio que se quería vislumbrar entre 
los intereses particulares y los del Estado: La Academia, después de tomar los informes convenientes sobre las circunstancias del descubrimiento, y clase y mérito de aquellas antiguallas, propuso a S.M. que se mandase suspender su extracción y que se extendiese absolutamente esta providencia a todos los objetos de igual especie, como está resuelto por punto general para las pinturas. Así se estableció por real resolución el 25 de junio de 1806, y comunicada esta a la Justicia de Poza, se devolvieron los monumentos a los descubridores para que como dueños de ellos pudiesen libremente conservarlos o enagenarlos según les conveniese, proporcionándole de esta suerte la ventaja de que la nación quede en posesión de estos restos de antigüedad, y los particulares en el libre uso de su propiedad, para poder disponer a su arbitrio de lo que encontrasen o adquiriesen.

\section{LA CONFRONTACIÓN ENTRE EL DERECHO DE LA PROPIEDAD PRIVADA Y EL INTERÉS PÚBLICO EN EL SISTEMA TUTELAR DEL PATRIMONIO ARQUEOLÓGICO EN LA ESPAÑA ISABELINA}

Durante la etapa de Fernando VII se vivió un incipiente desarrollo de la Arqueología científica. Se asistió a una consolidación de la actividad de la Real Academia de la Historia en la inspección de antigüedades, gracias a la renovación de la Real Cédula de 1803 a través de dos circulares del Consejo de Castilla de 1818 y 1827 . Incluso cabe resaltar la propuesta de creación del Museo Español de Antigüedades, que sería el precedente del Museo Arqueológico Nacional. Como apunta Maier (2003: 40), se intensificaron en este momento los permisos de excavaciones concedidos por permiso real, especialmente en la etapa de la Década Ominosa (1823-1833). El cargo del Inspector de Antigüedades va a ser una de las novedades de este periodo: Nació en 1838, siguiendo el modelo que había sido creado en Francia el 23 de octubre de 1830 con la denominación de Inspector General des monuments historiques a propuesta del Ministro del Interior Guizot. Se adjudicó a individuos de reconocido prestigio en lo tocante a su dedicación a la conservación de las antigüedades. $\mathrm{Su}$ labor se centraba primordialmente en relación con bienes arqueológicos más que del Patrimonio Monumental. Sin embargo, no era la primera vez que la Real Academia de la Historia se había dedicado a la inspección de antigüedades, habilitada para esos menesteres por la Real Cédula de 1803, renovada por las circulares de 1818 y 1827, que todavía seguía en vigor en 1838 .
En realidad se trataba de dar un espaldarazo a su función de vigilancia de las antigüedades, en un momento en que se estaba produciendo una nueva organización administrativa del territorio en provincias, a raíz de la promulgación de la Real Orden de 30 de noviembre de 1833 , poniéndose al frente de cada una de las 49 provincias a los llamados entonces Subdelegados de Fomento primero, Jefes Políticos después, y finalmente Gobernadores Civiles, que fueron los que tendrían a su cargo la obligación de proteger las antigüedades. De esta manera el cargo de inspector de antigüedades nacía en función a la nueva realidad administrativa del país, adoptando el papel que hasta este momento había protagonizado la Real Academia de la Historia.

No cabe duda de que las excavaciones arqueológicas se incrementaron considerablemente en los años de las Regencias, en un momento en que la búsqueda de las antigüedades se había convertido en un objeto primordial de muchos investigadores, eruditos y académicos de la historia primordialmente, a lo que se unió la iniciativa estatal que veía en las antigüedades una referencia esencial en la reconstrucción de la historia nacional. El conflicto jurídico estaba servido, y se prolongaría durante toda la etapa isabelina, especialmente debido a la localización de estos bienes específicos del Patrimonio Histórico-Artístico, ya que un gran número de ellos se encontraban situados en los fundos privados. Surgía nuevamente el problema de su tutela pública, de su régimen patrimonial, al considerarse dueño de los mismos al propietario del lugar donde se habían encontrado, o al descubridor.

Había nacido un Patrimonio Especial que, aunque identificado como una rama de la historia del Arte, se iría abriendo camino hasta desarrollar un régimen jurídico específico, distinto al utilizado en el caso del resto de las obras artísticas. En esta etapa las disposiciones de la Cédula de 1803 siguen estando vigentes, por lo que en el caso de que hubieran sido descubiertos en una propiedad privada, pasaban a manos ajenas a lo público, bien a su descubridor, bien al propietario del fundo donde se había encontrado, de manera que el Estado apenas podía intervenir sobre ellos, salvo la de adquirirlos a cambio de una indemnización, pero siempre con la libertad de venta del propietario. La cuestión cambiaría si el terreno en cuestión fuera público o de la Corona, como se disponía en el artículo $2^{\circ}$ de la Real Cédula.

Las excavaciones arqueológicas adquirieron entonces un rango oficial al tener que ser autorizadas por los gobernadores civiles, aunque su nombramiento debía ser consultado a la Real Academia de la Historia, lo que suscitó numerosos conflictos de jurisdicción en la tutela 
patrimonial. La Administración intervino en el ámbito de la propiedad privada, aunque no cabe duda de que con grandes limitaciones, como se deduce de las actas de la Real Academia de la Historia de este momento. El caso de las excavaciones de Cártama se puede considerar paradigmático en la manera de intervenir el Estado a instancias de la Real Academia de la Historia en una propiedad privada, ya que al conocerse la existencia de antigüedades en el subsuelo de un caserío se plantearía la compra de las mismas, y el posterior derribo. De esta manera, por la Real Orden del 13 de febrero de 1834, se ordenó a la Academia que informase de la importancia de estas excavaciones antes de resolver la adquisición del caserío, así como su derribo. Unos días después, el 14 de marzo de 1834, la Academia de la Historia, después de oír a la Comisión creada para ello, propuso no derribar las casas debido al alto coste que suponía, aunque se dejaba la posibilidad de excavar en los corrales y patios del caserío. Según los resultados que se obtuviesen, se dispondría el derribo de las casas. El 18 de marzo de 1834 nuevamente la Real Academia recibió una Real Orden del Gobierno en la que se solicitaba noticias de las excavaciones que se estaban realizando en Cártama.

Una de las características en la forma de actuar el Estado fue su propia inercia en configurar una verdadera institucionalización administrativa que pudiera proteger a las antigüedades descubiertas. La incompetencia de la Administración va a quedar reflejada en el contenido del Informe que da la Real Academia de Bellas Artes de San Fernando del 18 de febrero de 1836, en el que, con motivo del descubrimiento de un mosaico en Mérida, se acoge la noticia con placer, por el que nos inspira el ilustrado celo de aquel Gobernador; con sentimiento, porque preveemos que su descubrimiento tendrá la suerte de los mosaicos de Itálica, y de otros monumentos apreciabilisimos. Muchos preciosos restos de antigüedades, que poseíamos, solo subsisten ya en la memoria de los aficionados á esta importante rama de la historia, y en los dibujos levantados por extrangeros, cuia solicitud en darse ellos conocimiento al público, y en escitar el deseo de verlos y examinarlos contrasta con el exquisito instinto que tenemos los españoles para destruir a toda prisa y borrar hasta los vestigios de las nobles artes de nuestra patria. Sin embargo, en esta ocasión se exalta el papel desempeñado por el gobernador militar de Mérida, D. Mariano de Albo, tal vez único en su especie (se refiere al gobernador, no al mosaico), por las gestiones que ha realizado en la protección de un mosaico encontrado. La actitud del gobernador y del propio Ayuntamiento era algo inusual en la época, y lógicamente colisionó no sólo con los intereses particulares del propietario (según el Informe de la Academia, el mosaico se halla en el corral de una casa particular, alcanzándose a otros dos, y prolongándose el terreno por debajo de unas casillas miserables), sino también con el procedimiento realizado por la propia Administración, por la falta de interés y por la carencia económica, de manera que la Academia "pide al Gobierno que no solo disponga de (...) fondos municipales en la excavación, sino que se le autorice para gastar las que fuera necesarias con el fin de conservar lo descubierto, y cierta cantidad para proseguir las investigaciones y traslado lo que se encuentre a parte segura, donde se forme un museo" (Maier 2003: 120).

Se conocen intentos de particulares por adquirir derechos patrimoniales sobre los bienes que en principio, por su naturaleza, tenían que pertenecer al Estado. En este punto cabe mencionar la solicitud de autorización que pidió Domingo Rocchi, del Consejo de Su Majestad, el 11 de marzo de 1839 para iniciar excavaciones en Itálica, concediéndosele facultad para vender en el extranjero parte de los monumentos de antigüedad que se encuentren, con el pretexto de que al estar viviendo el Estado una situación de crisis política, se podía hacer un servicio público protegiendo las ruinas de Itálica: "El Gobierno en medio de su actual apuro no puede destinar a tan importante i costosa operación los fondos que son necesarios. Si un particular celoso pudiera llevarla a cabo con su propio capital, cediendo al erario una parte del valor de su descubrimiento, no cabe duda que S. M. se dignaría acoger su benevolencia, sus patrióticos deseos i concederles los aucilios que reclama para su empresa en el concepto de que ningún gravamen ha de imponer a los fondos públicos".

La primera concesión estaría referida al uso ilimitado de la delimitación del terreno donde debía de practicar las diversas excavaciones arqueológicas: "Se concederá al esponente bajo su propio nombre la facultad exclusiva de utilizar lo que se encuentran entre las ruinas de la antigua Itálica en toda la estension que se considere haber ocupado la ciudad $i$ de hacer las catas i escavaciones que se juzguen necesarias para el hallazgo de antigüedades, sin que corporación ni persona alguna pueda perturbarle en su trabajo (...)". Se planteaba el uso de una mano de obra procedente de las prisiones locales que estaban trabajando en obras públicas en este momento, a cambio de un montante económico y de respetar las condiciones humanitarias: "Para los trabajos expresados se facilitará al esponente hasta quinientos confinados a medida que lo solicite, $i$ la cuota correspondiente a numero, abonando un plus de medio real diario, $i$ tratarlo con la consideraciones 
debidas a la humanidad.". Como tercera condición, se establecía que todos los objetos encontrados fueran adquiridos en propiedad, "pudiendo disponer de ellos según su voluntad, u espedirlos al extranjero". Incluso se contemplaba que "los objetos que se vendan o se despachen para el extranjero desgravarán un veinte i seis por ciento de su valor en venta con tasación hecha por peritos nombrados por ambas partes", aunque dejaba a elección del Gobierno cuales eran los objetos con destinos a los Museos, academias u otros establecimientos públicos, i los tomará por un valor en tasación de los derechos expresados en el artículo anterior, $i$ habiendo asceso por una ú otra parte se hará recíprocamente el abono".

La Real Academia de la Historia informaría en contra para que no se permitiera a Domingo Rocchi la venta en el extranjero de los objetos de antigüedad que extrajese de Itálica, en el caso de que se le diese permiso para realizar excavaciones, poniendo como excusa que la legislación que se había promulgado desde Carlos III hasta este momento no permitía la salida de obras de arte al extranjero. "Pero a pesar de la situación lastimosa de nuestros días, cree la Academia que sería deshonroso permitir que se pusiesen a la venta los restos preciosos que quedan de los siglos pasados, y que por fortuna han resistido á los envates del tiempo (...). Aun cuando D. Domingo Ranchi quisiera hacer descubrimientos á su costa y formar un museo para instrucción de los anticuarios españoles, (...) manifiesta como principal objeto sacar fuera del país los fragmentos y reliquias de aquella célebre ciudad, i quiere no ser lo opuesto de semejante demanda con lo que con tanto acierto ordenaron los Sres. Reyes D. Carlos IV y Sr. Fernando VII ".

En el Informe de la Real Academia de la Historia se le instaba al Gobierno la obligación que debía de adquirir a la hora de realizar excavaciones arqueológicas, "personándose el Gobierno de que a nadie mejor que hacer que á él toca hacer excavaciones y formar un museo de antigüedades de un modo correspondiente a la dignidad de la Nación (...) le incumbe la obligación de mandar que nadie penetre en ellas excepto las personas instruidas a quienes mueva el amor a las ciencias y a las artes, poner guardianes que impidan toda extracción y en fin encargar a las autoridades el cumplimiento de lo que tantas veces se ha prevenido en esta materia. Este ha sido el clamor constante de la Academia desde que se les encomendó por S.M. la inspección de todas las antigüedades del Reino.

Con la de la mayoría de edad de Isabel II se fue desplegando una política proteccionista del Patrimonio Arqueológico, aunque no podemos afirmar que se solventasen definitivamente los problemas jurídicos generados en toda excavación arqueológica, ya que el conflicto entre el derecho de la propiedad privada y el interés general se convertiría nuevamente en el eje configurador de todo el ordenamiento del Patrimonio Cultural. Un rápido repaso del ordenamiento jurídico dedicado al Patrimonio Arqueológico nos ratifica tal hecho. Se fundó una serie de instituciones administrativas durante este largo reinado con el objetivo de proteger, primero mediante la creación de las Comisiones Científicas y Artísticas, que serían sustituidas por Real Decreto de 1844 por las Comisiones Provinciales de Monumentos Históricos y Artísticos, coordinadas o reguladas por una Comisión Central, presidida ésta por el Ministro de Gobernación, pero no por ello menguando las atribuciones que hasta ese momento había desempeñado la Real Academia de la Historia.

Un caso paradigmático sobre la reticencia de los particulares sobre los bienes arqueológicos adquiridos sería el del industrial y coleccionista Loring, quien adquirió para su colección personal las joyas epigráficas de las leyes municipales de Malaca y Salpensa, dos tablas de bronce romanas que pudo estudiar M. Rodríguez de Berlanga, quien formaría parte de la Comisión Provincial de Monumentos Históricos de Málaga. Animados por el éxito de la adquisición de estas piezas, incrementó su colección habilitando una finca que poseía fuera de la ciudad, llamada La Concepción, para instalar allí un museo de antigüedades de titularidad privada. De todos es conocida la petición de Loring en 1857 para adquirir como propiedad privada todos los bienes arqueológicos que encontrase en sus excavaciones en la provincia, y que la Real Academia de la Historia en mayo de 1858 le negó tal petición (Berlanga Palomo 2005: 79). No obstante, la existencia de una institución privada cuyos bienes no pertenecían al dominio público fue un hecho, y en principio quedó excluida la intervención estatal. No sería el único caso ya que las colecciones de antigüedades en manos privadas se fueron incrementando durante esta etapa.

La negativa de la Real Academia de la Historia a la solicitud de Loring destaparía una realidad jurídica: la escasa regulación sobre la propiedad de los bienes arqueológicos que fueran descubiertos por los particulares, por lo que se intentó desde esta institución la promulgación de una ley de antigüedades que regulase todos aquellos aspectos referentes al descubrimiento de hallazgos arqueológicos, especialmente en lo referente a la propiedad de los mismos. Por este motivo, la Comisión manifestaría que es difícil conciliar el interés nacional con el individual para que este último siempre respetable no se oponga ni se mengüe el interés 
nacional mucho más atendible, a lo que precisaría que no tenemos ley suficiente que fijando las reglas y adoptando las precauciones necesarias declare cuando y en qué forma y con qué indemnización haya de poderse entrar con objeto de investigar antigüedades en la propiedad agena, ya pública ya del Estado, ya particular en algunos casos, puntos ambos delicadísimos, ni tampoco ley que fije el destino que hayan de tener muchos de los objetos que pueden hallarse en tales investigaciones y sean dignos por su importancia de conservarse en los museos nacionales para la gloria del país y para los progresos de la ciencia: y además porque el Gobierno no debe tener en buenos principios y según las leyes una intervención directa y necesaria, ya para prevenir las contestaciones que pudieran ocurrir entre el descubridor y el Estado y los dueños de los terrenos en que se intente hacer el descubrimiento, ya también para determinar si todos los objetos han de ser del descubridor o se exceptuarán algunos que por su importancia deben conservarse en la nación y en el local que el Gobierno señale. Por Real Orden de 14 de diciembre de 1859 el Gobierno solicitaría a la Real Academia de la Historia que preparase el proyecto de Ley pero, como apunta Maier (2008), a pesar de las múltiples veces que fue reclamado por el propio Ejecutivo, nunca se llegó a atender la solicitud.

Los sucesivos reglamentos a raíz del desarrollo de la Real Orden de 1844 fueron ampliando las potestades administrativas de las Comisiones de Monumentos. Así, en el Reglamento de 15 de noviembre de 1854, se establecía como obligación de las Comisiones Provinciales dar conocimiento de los descubrimientos y adquisiciones de nuevos objetos artísticos y arqueológicos (art. 28.5). En el Reglamento de 1865 nuevamente se reguló el procedimiento de solicitud de permiso de las excavaciones arqueológicas, ya que las propuestas se debían alzar tanto al Gobernador como a la Real Academia de la Historia, convirtiéndose en el órgano directivo de toda la actividad arqueológica en España. Entre las atribuciones de las Comisiones Provinciales de Monumentos estaría la dirección de las excavaciones arqueológicas (art. 17.3), la creación, aumento y mejora de los Museos de Antigüedades (art. 17.4), la adquisición de estatuas, lápidas, relieves, medallas y cualquier otro objeto que merecieran figurar en los Museos Arqueológicos (art. 17.6), el reconocimiento facultativo y arqueológico de los monumentos públicos (art. 17.8), "la custodia y decorosa conservación de los sepulcros y enterramientos de nuestros Reyes, Príncipes o hombres ilustres", y la traslación y restauración de los que, por haber sido enajenados los edificios donde existían, o por su mal estado de conservación, lo exigiere (art.17.9). Igualmente, tenía como atribución la intervención en las obras públicas que se hicieran, ya con fondos municipales o provinciales, o a expensas del Estado, en despoblados antiguos, en las inmediaciones de las vías romanas, con el fin de evitar la pérdida o sustracción de los objetos arqueológicos que pudieran descubrirse (art. 17.10). En el artículo 19, entre las obligaciones de las Comisiones Provinciales, se establecía la atribución de hacer propuestas o informar sobre la manera y forma de practicar exploraciones arqueológicas en los despoblados de las antiguas ciudades, siempre que algún descubrimiento fortuito y la conveniencia de no malograrlo así lo aconsejara (19.2). Así mismo las Comisiones de Monumentos asesoraban sobre la adquisición de aquellos objetos arqueológicos, que sin ser propiedad del Estado ni de los pueblos, parecieran dignos por su antigüedad de ocupar un puesto en los museos provinciales (19.3), y podían suministrar cuantos datos y noticias fuesen requeridos para la mejor resolución de los expedientes relativos a las Antigüedades (art.19.4)

Al mismo tiempo, los Gobernadores Civiles estarían a la disposición que marcara la propia Comisión Provincial de Monumentos, a menos que hubiese una urgencia en la intervención (art. 20). De esta manera la Comisión Provincial tendría una prioridad sobre los Gobernadores Civiles para proponer la adquisición de objetos de antigüedad, por lo que evitaría, en cuanto fuese compatible con el derecho de la propiedad, que estos objetos saliesen del territorio nacional (art. 21.6). En el artículo 24 se delimitarían aún más las obligaciones de las Comisiones Provinciales sobre las excavaciones arqueológicas con respecto de la Real Academia de la Historia. Para ello se debían proponer las excavaciones que debían de hacerse en los despoblados y sitios donde hubiera existido importantes construcciones antiguas (art. 24.1), elevar a su conocimiento las oportunas notas de los objetos en que estas excavaciones se descubriesen (art. 24.2), dar cuenta de todo descubrimiento fortuito que en la provincia se hiciese manifestando, si fuera posible, su adquisición (art. 24.3), y remitirle oportunas notas de cuantos objetos arqueológicos se encontrasen, al llevar a cabo las obras públicas a la que se refería el artículo 17.10 (art. 24.4).

La autorización de la Real Academia de la Historia para que las Comisiones Provinciales promovieran excavaciones arqueológicas se conviritó en un verdadero requisito administrativo (art. 25), al mismo tiempo que también tendría que estar autorizada por la institución la adquisición y compra de antigüedades (art. 26). A los Alcaldes de los pueblos también se le designarían algunas obligaciones respecto a las Comisiones 
Provinciales, entre las que destacamos el auxilio de sus miembros para el desarrollo de su trabajo (art. 43.2), la recogida de antigüedades, expresando el lugar donde fueran hallados y las circunstancias especiales del descubrimiento (art. 43.3).

\section{LA QUIEBRA DEL DERECHO ABSOLUTO DE LA PROPIEDAD PRIVADA EN EL ÁMBITO DEL SISTEMA TUTELAR DEL PATRIMONIO ARQUEOLÓGICO EN LA ETAPA DE LA RESTAURACIÓN}

Con la promulgación del Código Civil de 1889, se daría un paso fundamental en la legislación sobre los hallazgos arqueológicos, ya que aunque todavía se consideraba el tesoro oculto como un bien perteneciente al dueño del terreno en que se hallase, se presentaba como novedad el hecho de que cuando el descubrimiento se hiciera en propiedad ajena o del Estado, y por causalidad, la mitad se aplicaría al descubridor; y que el propio Estado podría adquirirlo por justo precio si tuviera interés para las artes o las ciencias (art. 351). De esta manera, los bienes arqueológicos serían identificados como tesoro, y por consiguiente se estaba aplicando el régimen legal del tesoro oculto que la doctrina y la propia codificación civil habían delimitado.

La construcción jurídica del Bien Arqueológico como un objeto material de valor antiguo que había perdido su dueño, y que casualmente o a través de una excavación organizada se encontraba, enlazaba con la tradición legal y doctrinal española sobre los conceptos de ocupación, hallazgo y tesoro. De esta manera, el Libro Tercero del Código Civil que trata de las diferentes formas de adquirir la propiedad, se inicia con la afirmación de que la propiedad se adquiere por la ocupación. En el artículo 610 se estableció que se adquiriría por ocupación los bienes apropiables que por naturaleza carecían de dueño, entre ellos los tesoros ocultos. Los restantes artículos contendrían la llamada por la doctrina "ocupación de las cosas inanimadas"; según el artículo 614, el que por casualidad descubriese un tesoro oculto en propiedad ajena, tendría el derecho que le concedería el artículo 351 del Código, o sea, que se le concediera la mitad del beneficio. Todos los artículos referidos por el Código se ocupan de hallazgos de cosas muebles que carecen en principio de posesión, aunque en sí misma no hay una sola modalidad, sino múltiples variedades, siendo la del tesoro la que nos interesa. Sin entrar en la polémica doctrinal del concepto de "tesoro", ya en el artículo 716 del Código Napoleónico se consideraba un tesoro una cosa encontrada oculta.
Esta concepción se proyectó en los códigos italianos decimonónicos y en el propio Código Civil, concretamente en el artículo 352, en el cual lo define como depósito oculto e ignorado, a lo que se uniría el desconocimiento de su legítima pertenencia, tesis criticada por Pampaloni, pero que la mayoría de las doctrinas han recogido posteriormente. Desde esta perspectiva, Moreu apunta como, a diferencia de la mayoría de los códigos del siglo pasado, el español incorporó en la regulación del tesoro un precepto, existente ya en el proyecto de 1851 , en su artículo 395, por el que se reconocía derechos al Estado sobre objetos descubiertos de interés científico o artístico, que se incorporaría en el Código Civil en el párrafo $3^{\circ}$ del artículo 351 , en el que se precisaba que aquellos efectos que fuesen interesantes para la Ciencias o las Artes, el Estado podría adquirirlos por su justo precio (art. 395).

La propia doctrina de la época consideraría esta potestad del Estado como una expropiación de bienes muebles, cuando aún todavía la Ley de Expropiación Forzosa solo contemplaba el caso de los bienes inmuebles (Ley de 10 de enero de 1879). Sin embargo, esto no significaba una adquisición automática de la propiedad de los objetos de interés artístico, sino que se trataba de una opción de adquisición en su favor del tesoro regularmente adquirido desde el descubrimiento por el dueño del lugar. De esto se deduce que el Estado no siempre podría adquirir la propiedad del bien descubierto, y cuando lo hiciese se procedía en todo caso a una verdadera adquisición por el descubridor y el dueño del lugar mediante, respectivamente, la ocupación y la accesión. Cabe mencionar cómo el criterio de la discrecionalidad del Estado en la adquisición sería defendida por la sentencia de la Sala $4^{\circ}$ de lo Contencioso Administrativo del Tribunal Supremo de 25 de octubre de 1933 (Moreu 1980: 664).

Sin duda una de las novedades fundamentales de comienzos del siglo XX fue la promulgación de la Ley del 7 de julio de 1911 y su Reglamento, el Real Decreto de 1 de marzo de 1912, por el que se establecieron las reglas a que han de someterse las excavaciones arqueológicas y la conservación de las ruinas y antigüedades. Antes de la promulgación de la Ley, se plantearon varios proyectos de Ley: los propuestos en 1900 por el Ministro de Instrucción Pública, García Álix; en 1904 por Domínguez Pascual; y en 1908 por Rodríguez San Pedro.

En estos ensayos, el artículo $1^{\circ}$ ya aclaraba el contenido del concepto: "Las remociones deliberadas y metódicas de terrenos respecto a los cuales existan indicios de yacimientos arqueológicos, ya sean restos de construcciones o restos de antigüedades". Al mismo 
tiempo se regulaba ya el patrimonio paleontológico: "Quedan también a los preceptos de esta Ley las excavaciones que se hicieren en busca de restos paleontológicos, siempre que en ellas se descubrieren objetos correspondientes a la arqueología". No obstante, en el Reglamento de 1912, en el artículo $1^{\circ}$, se ampliaba el concepto de excavación al considerar también como tal los trabajos de rebusca arqueológica que tuvieran carácter espeleológico o submarino y otros similares. Siguiendo a la profesora Yáñez y Lavín, la Ley de 1911 admitía la existencia de un método arqueológico, aunque solo sea referido a las excavaciones. Se establecía, por consiguiente, el concepto de excavación, introduciendo la metodología arqueológica de carácter científico como fundamento para identificarla como tal. La distinción que hace el legislador entre ruinas y antigüedades estaría fundamentada entre la concepción de bienes inmuebles y muebles. Sin embargo, nuevamente la dimensión temporal marcaría la tutela pública del $\mathrm{Pa}$ trimonio Arqueológico al considerarse digno de protección estatal aquellos bienes, entre ellos los arqueológicos, que tuviesen una antigüedad anterior al reinado de Carlos I, por lo que aquellos que perteneciesen a un periodo posterior no eran considerados dignos de protección por parte de la Ley de 1911, por lo que permanecerían en el régimen común de tesoro.

El tratamiento jurídico de las excavaciones arqueológicas y de los hallazgos de bienes muebles e inmuebles arqueológicos que estuviesen tanto en dominio particular como público en principio quedaría igualado, y así se delimitaba aún más el carácter demanial de los bienes hallado. No cabe duda que la potestad del Estado se incrementó no solamente en el ámbito de los fundos públicos, sino en la propia esfera privada, limitando la actuación de sus poseedores tanto en sus derechos de disposición como de gozo. Al mismo tiempo, el Estado va a ir adquiriendo la propiedad de aquellos bienes arqueológicos (tanto ruinas como antigüedades) que considere dignos de formar parte en el Legado Patrimonial; y se dotó de unas prerrogativas administrativas especiales, como fueron el derecho de tanteo y retracto, un sistema sancionador en el caso que los particulares infringieran la ley, e incluso la capacidad de poner en marcha excavaciones en los propios fundos privados con la correspondiente indemnización a sus legítimos dueños.

Como muestra de la nueva realidad jurídica que significó la promulgación de la nueva ley de 1911 y su Reglamento de 1912, podríamos abordar el caso significativo de la declaración del expediente de utilidad pública en la intervención del Estado con respecto a la necrópolis púnica de Ebusus, previa a ser declarada
Monumento Nacional, con el fin de que los particulares no pudieran intervenir en la misma, y por la que, en virtud del artículo $4^{\circ}$, pasaron a la propiedad del Estado. Como podemos apreciar la gran novedad que se plantea en el contenido de la Ley es la rápida intervención del Estado en los fundos privados fundamentándose en el interés general que se inserta en el propio bien. Con este objetivo, se delimita un expediente de utilidad pública (art. 4) por el que "El Estado se reserva el derecho de hacer excavaciones en propiedades particulares, ya adquiriéndolas por expedientes de utilidad pública, ya indemnizando al propietario de los daños y perjuicios de la excavación ocasione en su finca, según tasación legal'. Al mismo tiempo, la intervención del Estado estaría fundamentada en la potestad que se le concedía en la Ley de Expropiación Forzosa de 10 de enero de 1879, en su artículo 54.

A la vez que se precisa la intervención administrativa, se delimita la propia adquisición de la propiedad de los bienes tanto muebles como inmuebles encontrados en dicho fundo privado: "las ruinas, ya se encuentren bajo tierra o sobre el suelo, así como las antigüedades utilizadas como material de construcción en cualquiera clase de obras, podrán pasar a la propiedad del Estado mediante expediente de utilidad pública y previa la correspondiente indemnización al dueño del terreno y al explorador, si existiere" (art. 4.2). La diferencia con la normativa anterior residía en que en el caso del Código Civil la adquisición de los bienes arqueológicos para el Estado era facultativa, mientras que a partir de ese momento su adquisición fue necesaria. Incluso en el artículo $8^{\circ}$ del Reglamento se establecía el derecho del Estado a hacer excavaciones en propiedades particulares, convirtiéndose en uno de los pilares más progresistas de la nueva legislación, ya que se estaba acometiendo la intervención en la propiedad privada, alegándose la utilidad pública, aunque se indemnizaría al propietario de los daños y prejuicios de la excavación, tras una tasación.

Este hecho no significa que no fuera viable la existencia de un derecho de la propiedad privada sobre los bienes arqueológicos, ya que no cabe duda de que se mantuvo el coleccionismo erudito, incentivándose incluso la existencia de Corporaciones Científicas de ámbito particular, tanto nacionales como extranjeras, en unos años que se estaba iniciando una incipiente arqueología científica en España. Sin embargo, el descubrimiento de los efectivos por parte de éstas tendría que ir acompañado de una tutela pública, que en muchos de los casos permitía que se quedasen en la esfera de su propiedad particular, siempre que se respetara las limitaciones impuestas por la ley. El derecho de 
los particulares quedaba limitado con respecto a etapas anteriores, reflejo de la superación del derecho absoluto de la propiedad privada. El bien arqueológico había dejado de considerarse un mero objeto patrimonial de la esfera privada para convertirse en un bien de interés público, por lo que su función social (cultural) de exaltación de los valores nacionales en este momento marcaría el nuevo destino de este patrimonio específico. Todos los bienes arqueológicos que se encontraran en el suelo patrio se considerarían como bienes pertenecientes a la nación, por lo que se fue proyectando un procedimiento administrativo por el que el Estado controlaría todas las excavaciones que se fueran a realizar no solamente en los fundos públicos, sino también en los privados.

La necesidad de una autorización administrativa para realizar excavaciones arqueológicas marcaría una nueva realidad en el ámbito del Patrimonio Arqueológico. Es el Estado el que otorga la autorización de las excavaciones arqueológicas mediante una concesión administrativa. Siguiendo la tesis de Moureau, lo primero que cabe señalar es que, a diferencia de lo que ocurría con los tesoros y con las aguas subterráneas, y a pesar de la declaración genérica del artículo 350 del Código Civil por el que el dueño de una finca podía hacer en ella las excavaciones que quisiera, éste no podría hacerlas para buscar antigüedades o ruinas, debiendo solicitar la autorización del Estado y someterse a su inspección (art. 7 de la Ley y art. 14 del Reglamento). Otra novedad será la concesión de autorización no solamente a las Corporaciones Oficiales del Estado, tanto para hacer excavaciones en terrenos públicos como en privados, sino también a las Sociedades Científicas, que tendrían como obligación que la excavación contara con metodología científica, pues en caso contrario la concesión sería anulada.

El destino de los bienes encontrados por estas Sociedades Científicas estaría plenamente regulado ya que, aunque en principio podían tener la posesión de los mismos, el concesionario español no podría vender ni exportar los objetos procedentes de las excavaciones sin permiso de la Dirección General. En el caso de los descubridores extranjeros, se consideraban de pleno dominio un ejemplar de todos los duplicados que descubriesen y tendrían durante cinco años el derecho exclusivo de reproducción por procedimientos que no menoscabasen la conservación de los hallazgos. Incluso podrían llevarlos al extranjero con el fin de estudiarlos, compararlos y clasificarlos siempre que se comprometiesen a devolverlos al Estado en el plazo de un año. En el artículo $8^{\circ}$ de la Ley se disponía la disposición de la propiedad de los descubrimientos a aquellas Corporaciones bajo cuyos auspicios se habían realizado las excavaciones; en el caso de su disolución podía ser adquirido por la localidad donde se hubiese encontrado dichos bienes. Según Moreu (1980), el contenido del precepto estaría relacionado con la pretensión del legislador de atraer a la iniciativa privada a este tipo de excavaciones.

La transmisión del bien arqueológico como cualquier bien patrimonial entre particulares quedaría al mismo tiempo limitado, y así plasmaría su naturaleza jurídica especial si se compara con otros bienes materiales. En principio, sería autorizada la libre disposición del objeto al particular, pero con unas limitaciones: $1^{\circ}$ ) En caso de que fuesen objetos no duplicados, estarían autorizados incluso a exportarlos, siempre que fuesen devueltos a España en el periodo de un año y estuviese autorizado por el Ministerio (art. 17 del Reglamento); $2^{\circ}$ ) podrán transmitirlos por herencia, con la excepción de que en caso de que fuese una serie completa y tuviese que separarse los ejemplares que la formaban -con la consecuente pérdida de valor-, el Estado adquiriría la colección completa, previo pago de la cantidad que fuese tasada (art. 18 del Reglamento); $3^{\circ}$ ) En el caso de los poseedores de antigüedades, conservarían su derecho de propiedad de las mismas sin otras restricciones que las de inventariarlas y satisfacer un impuesto de $10 \%$ en caso de exportación, reservándose siempre el Estado los derechos de tanteo y retracto en las ventas que aquellos pudieran otorgar.

A pesar de la libertad de disposición, con una limitación exigua que se le proporciona al propietario, se establece un verdadero procedimiento sancionador, que regula el Reglamento en las siguientes ocasiones: $1^{\circ}$ ) En caso de que los poseedores de antigüedades autorizados por el Estado no redactaran el inventario, podrían ser declaradas de ocultación, y deberían ser valoradas por una Comisión de académicos de números de las Reales Academias de Madrid (art. 20 de Reglamento); $2^{\circ}$ ) En caso de que las exploraciones no fuesen autorizadas, los particulares estarían sujetos a responsabilidad, indemnización y pérdida de las antigüedades descubiertas. También serían sancionados aquellos que ocultasen, deteriorasen o destruyesen ruinas o antigüedades. La indemnización a pagar será establecida por el Estado, o bien el comiso (art. 22 del Reglamento); y $3^{\circ}$ ) Se podrían anular las concesiones de autorización a particulares y Corporaciones para hacer excavaciones en terrenos públicos o particulares, por causa grave, siempre que lo disponga el Tribunal establecido por la Ley (art. 23). Muy progresista es la inclusión del punto referido a que se consideraría causa grave el que los trabajos no se practicasen de modo científico, en un 
momento en el que muchas excavaciones arqueológicas eran fruto de las actividades de aficionados.

La nueva normativa también regularía la figura del descubridor del hallazgo arqueológico, introduciéndose nuevamente la recompensa en metálico por el descubrimiento de los bienes. Como indemnización, recibiría al hacer entrega de los efectos encontrados la mitad del importe de la tasación legal de dichos objetos, correspondiendo la otra mitad al dueño del terreno (art. $6^{\circ}$ del Reglamento de 1912). En el artículo 7 del Reglamento se precisaba que en el caso de que se descubriese en obras públicas daría un premio en metálico, con una equivalencia de su valor intrínseco, si el objeto es de metal o de piedras preciosas, y en los demás casos, le indemnizará con arreglo a la tasación legal a la que se refiere el artículo $6^{\circ}$ del Reglamento. El artículo $25^{\circ}$ del Reglamento precisaba que el Estado concedería cada tres años dos premios en metálico y uno honorífico a los tres exploradores que hubiesen logrado descubrimientos de mayor importancia, a juicio de una Comisión calificadora. Al mismo tiempo el Estado podía conceder la propiedad al descubridor del objeto (art. 15 del Reglamento).

Otra de las novedades que aportaría la normativa sería el derecho de tanteo y retracto que asume la Administración Estatal, reflejada en el artículo $21^{\circ}$ del Reglamento, al mismo tiempo que el Ministro podría acordar la sustitución de su derecho en los casos de las Corporaciones oficiales y en los particulares que diesen garantía bastante, con el reconocimiento de la propiedad en el Estado (art. 21.2 del Reglamento).

Sin embargo, esta ley no daría el resultado esperado ya que faltaron los medios económicos y humanos para hacerla cumplir, aunque no por ello dejó de tener una amplia vigencia temporal. Es significativo en este caso cómo todavía en la sentencia dada por el Tribunal Supremo el 22 de marzo de 1976 en el caso del hallazgo de la Dama de Baza, se inclinase por el sistema de opción de adquisición por el Estado y no por la adquisición automática que ya estaba recogida en el artículo $5^{\circ}$ de la Ley de 1911, lo que ha motivado la critica doctrinal de dicha sentencia.

\section{A MODO DE CONCLUSIÓN}

Las distintas promulgaciones que se han desarrollado desde los gobiernos ilustrados hasta el final del periodo del régimen liberal dieron pasos fundamentales en la configuración del Patrimonio Arqueológico como Dominio Público. No cabe duda de que fue la transformación del papel del Estado en la intervención de las excavaciones arqueológicas y sus correspondientes hallazgos la que marcaría el verdadero cambio en el sentido jurídico del sistema normativo. Así, del criterio de discrecionalidad de los bienes arqueológicos por parte del Estado marcado por el Código Civil de 1889, se pasaría a un criterio de adquisición automática del Estado como plantearía el artículo 5 de la ley de 1911, y recogería posteriormente el artículo 44.3. de la ley de 1985 .

\section{APENDICE DOCUMENTAL*}

I. Descubrimiento de monedas de plata árabes en un fundo privado, y reclamo por el propietario de su propiedad, en cumplimiento de la Real Cédula de 1803.

Minuta de oficio en que se le comunica que remita las monedas árabes aparecidas en Córdoba para que la Academia las examine y tome las medidas oportunas al respecto.

D. Isidoro Bosarte, secretario general de la Academia de las Nobles Artes me pasó como secretario perpetuo de la Real Academia de la Historia, que corresponde al conocimiento del asunto, el papel de V.S. de 8 de este mes, en que se sirve las cuentas del descubrimiento hechas cerca de esa ciudad de unos huesos como de cadáver y de una porción de monedas de plata árabes de 52 onzas de peso, al tiempo de ejecutar una excavación en la casa abierta por la construcción de un edificio. Y habiéndolo hecho presente todo a la referida Academia de la Historia ha acordado que (...) resolver en la materia con el debido conocimiento se hace preciso que V.S. me remita, no hallando inconveniente en ello, las expresadas monedas por persona de su confianza, para examinarlas debidamente, se tomarán las medidas oportunas, avisando de su resolución á V.S. (...) Madrid, 17 de junio de 1806.

Oficio en que se informa que las monedas de época árabe descubiertas en Arco de la Sierra serán remitidas a la Academia por Nicolás Díaz.

A consecuencia de la instancia de la Academia de la Historia, que V. me comunicó (...) para que remitiese la porción de monedas de plata árabe, con peso de 52 onzas hallados en una excavación que estaba haciendo en

\footnotetext{
* Todos los documentos forman parte de los fondos documentales pertenecientes a la Real Academia de la Historia. La trascripción es del autor.
} 
la hacienda en el Arco de la sierra de esta ciudad, con persona de mi confianza, lo ejecuto con Nicolás Díaz, vecino de esta ciudad y ordinario para esta Corte, el conducto más seguro (...). Córdoba, 31 de julio de 1806.

Oficio de D. Francisco Beltrán de Guevara, secretario del Cabildo de la Catedral, dueño de las monedas árabes descubiertas pide a la Real Academia de la Historia que se les devuelva o se le abone su valor en dinero.

D. Francisco Beltrán de Guevara, secretario del Cabildo de la Santa Madre Iglesia Catedral de esta ciudad, vecino de ella, a V. con el debido respeto dice: Que habiendo proyectado ensanchar una casa de campo que tiene en heredad propia (...) principió las obras y en unas de las zanjas que se abrieron para sacar el cimiento se halló un tarro de barro que contenía porción de monedas o medallas de plata con caracteres arábigos; de cuya intención dio cuenta al Juzgado de esta intendencia donde se entregó las monedas cumpliendo lo prevenido en la Real Orden de 6 de julio de 1803: Y aunque con arreglo a sus artículos $1^{\circ}$ y $2^{\circ}$ solicitó se le devolviesen, o su valor, hasta ahora no lo ha conseguido. Con este motivo, y el de haberse enviado a esa Real Academia las monedas, le ha parecido oportuno a V. como también que con el objeto de proporcionar la intención de de algún otro monumento de que tal vez, fuese indicio aquellas monedas, continuo las excavaciones en el concepto de que con el valor de ellas podría reducir los crecidos costos de las excavaciones y lo que gastó en gratificar a los operarios que se ocupan en la abertura de la zanja en el tiempo de la intervención (...)

A cuyo efecto: Suplico se sirva dar las órdenes más oportunas y eficaz para que se devuelvan y entreguen al exponente tales monedas; o su justo valor, cumpliendo así con la V. resolución (...) Córdoba, 31 de julio de 1806.

Minuta en que se le comunica al legítimo propietario el acuerdo de la Real Academia de la Historia por el que se le devuelve o abonará la cantidad correspondiente por las monedas descubiertas en su propiedad.

Como Secretario perpetuo de la Real Academia de la Historia he dado cuenta a este cuerpo literario de la del 31 de julio próximo ha acordado en su vista que reconocidas las monedas de plata árabes presentada al mismo tiempo con la mayor brevedad posible, tomará la resolución conveniente para que se le devuelvan a V. como dueño del descubrimiento o se le reintegre de su valor, dando el aviso oportuno al Intendente de esa ciudad para que han sido remitidas. Madrid, 26 de agosto de 1806.

Minuta de oficio en la que se comunica que la Academia adquiere a cambio de un precio metálico las monedas arábigas encontradas en terreno de un particular

La Real Academia de la Historia ha examinado las monedas de plata árabes que fueron descubiertas en las excavaciones hechas en terreno de la pertenencia de V. y remitidas por el Intendente de esta ciudad, y aunque nada tienen de particular o extraño en la numismática arábiga, y la Academia posee estas y otras diferentes de los mismos reyes a que pertenecen, ha acordado separar para su museo 12 de ellas por hallarse mejor conservadas y me encarga se lo manifieste a $\mathrm{V}$. y le proponga su compra, siempre que sea solo al peso, por ser comunes y no merecer otra estimación. Si conviniese a V. este partido, se le remitirá el dinero por medio de la persona a que se entreguen las demás para devolverlas al Intendente de cuyas manos podrá recogerlas (...). Madrid, 2 de septiembre de 1806.

Minuta de oficio en que se informa de la devolución de las monedas árabes a Nicolás Díaz para que se le entregue a su dueño, excepción de 12 que pasan a formar parte del Museo de la Academia.

Por acuerdo de la Real Academia de la Historia devuelvo a V. las monedas de plata árabes que me remitió el 31 de julio próximo con el Ordinario de esa ciudad, Nicolás Díaz, quien las conduce, porte pagado, para que las haga V. entrega a su dueño D. Francisco Beltrán de Guevara, a excepción de doce que (...) se han separado para el museo de la misma Academia. Madrid, 13 de septiembre de 1806.

II. Respeto al derecho de la propiedad privada en los descubrimientos de antigüedades en la localidad de Poza de Sal.

Minuta de oficio en que se advierte que las antigüedades halladas en Poza de Sal no puede viajar a Roma, al establecerse por la Real Cédula de 1803 que la Academia la inspección de todos los monumentos de Antigüedad.

La Real Academia de la Historia a la S.M. se dignó confiar la inspección de las antigüedades que se descubran en todo el reino por Real Cédula de 6 de julio de 1803 ha llegado a entender que cerca de la población de 
Salas de Bureba, ha encontrado un labrador cavando en su viña varios sepulcros con cadáveres muy bien conservados y al pie de uno dos platos, dos vasos lacrimatorios de vidrio y una especie de calderillo de cobre, cuyos monumentos parece que han conducido a casa del Alcalde Don Pedro Pablo Echevarría con el objeto de un sujeto residente en Roma por las de un religioso premostratense de la ciudad de Valladolid. Y no pudiendo menos de extrañar la Academia que no solo haya dado noticias de tales descubrimientos como S.M. manda en otra Real Cédula que acompaño a $\mathrm{V}$ de un ejemplar impreso, por si acaso no la hubiesen tenido presente, ha acordado que les pase el oficio oportuno, como lo ejecuto, para que suspendiendo desde luego de los indicados monumentos de antigüedades, me remitan relación circunstanciada de la excavación y descubrimiento hecho en los términos prevenidos por el Rey en la Instrucción que tuvo a bien aprobar (...) Madrid, 11 de junio de 1806.

Informe de la Sala de Antigüedades en el que se concluye que mientras que la Academia verifique los hechos, se suspenda la extracción de los monumentos depositados en la casa del Alcalde de Poza de la Sal, que pretende exportarlos a Roma.

La sala de Antigüedad ha visto la representación de D. Gregorio González, dirigida por el Excmo. Sr. Don Pedro Ceballos para informar a la Academia. En ella refiere ciertos descubrimientos de Antigüedad junto a la Villa de Poza, y que habiéndose hallados nuevos monumentos (...) el teniente alcalde ha prohibido se continúen las excavaciones (...) y que por punto general se prohíba la extracción a semejantes objetos fuera del reino. La Sala ha tenido presente la Real Cédula en que el Consejo inserta y manda observar la Instrucción formada por nuestra academia sobre el modo de recoger y conservar los monumentos antiguos que se encontraran en el reino. En el artículo $2^{\circ}$ de esta Instrucción se establece que serán dueños de todos los monumentos descubiertos los que lo hallasen con sus heredades y casas o lo descubran a su costa y por su industria, con sola la carga de dar parte y noticia circunstanciada a la Academia por medio de su secretario (...) Madrid, 13 de junio de 1806.

Oficio por el que se solicita sean devueltos los objetos descubiertos y depositados en la casa del alcalde de Pozo y Sal a su legítimo dueño.

Muy Señor Mío. Habiendo tomado la Real Academia de la Historia las noticias oportunas acerca de los monumentos antiguos descubiertos en el término de esa villa, y depositados en poder de V. ha acordado que proceda a entregarlos a las personas que le corresponde su propiedad, con la condición de que no se extraigan fuera del Reino, como su S.M. tiene mandado, y asimismo que en adelante cuide $\mathrm{V}$ de dar parte al mismo Real Cuerpo de cualquiera otras antigüedades que se hallen en las excavaciones y se ejecuten, remitiendo, si hubiese proposición, dibujo de todo. 23 de julio de 1806.

\section{Tutela del Patrimonio Arqueológico durante el reinado de la Reina Regente $D^{a}$ María Cristina.}

\section{Instancia en que se solicita la autorización para iniciar excavaciones en Itálica, concediéndole fa- cultad para vender en el extranjero parte de los monumentos de antigüedad que se encuentren 11 de marzo de 1839}

Señor D. Domingo Rocchi del Consejo de Su Majestad (...) con el más profundo respeto expone: Que son bien conocidas las ruinas de la antigua Itálica visitadas por todos los curiosos que transitan por Sevilla, en cuyas inmediaciones se hallan aquellas, al paso que abandonadas a la ignorancia i rustosidad de algunos habitantes del pueblo contiguo se degradan todos los días sus venerables monumentos. Se destinan sus despojos a viles usos, con mengua de la ilustración nacional i sin provecho alguno para el erario. El esponente por varios informes ha adquirido la certidumbre de que practicando sobre el terreno excursiones bien dirigidas podrían todavía encontrar antigüedades preciosas que darían una gran luz a la historia i nueva gloria a nuestras artes florecientes bajo la dominación romana. El Gobierno en medio de su actual apuro no puede destinar a tan importante i costosa operación los fondos que son necesarios. Si un particular celoso pudiera llevarla a cabo con su propio capital, cediendo al erario una parte del valor de su descubrimiento, no cabe duda que S. M. se dignaría acoger su benevolencia, sus patrióticos deseos i concederles los aucilios que reclama para su empresa en el concepto de que ningún gravamen ha de imponer a los fondos públicos. Sobre estas bases i con los mejores deseos i esperanzas de proporcionar un bien a la nación i un título de esplendor al reinado actual, somete a la Real aprobación de V. M. las proposiciones siguientes:

$1^{\circ}$ Se concederá al esponente bajo su propio nombre la facultad exclusiva de utilizar lo que se encuentran entre las ruinas de la antigua Itálica en toda la estension que se considere haber ocupado la ciudad i de hacer las catas i escavaciones que se juzguen necesarias para 
el hallazgo de antigüedades, sin que corporación ni persona alguna pueda perturbarle en su trabajo (...).

$2^{\circ}$ Para los trabajos expresados se facilitará al esponente hasta quinientos confinados a medida que lo solicite, i la cuota correspondiente a numero, abonando un plus de medio real diario, i tratarlo con la consideraciones debidas a la humanidad.

$3^{\text {o }}$ Serán propiedad del esponente los objetos que se estraigan de sus rebuscas y excavaciones pudiendo disponer de ellos según su voluntad, u espedirlos al extranjero.

$4^{\circ}$ Los objetos que se vendan o se despachen para el extranjero desgravarán un veinte i seis por ciento de su valor en venta con tasación hecha por peritos nombrados por ambas partes.

$5^{\circ}$ El Gobierno podrá escoger los objetos con destinos a los Museos academias u otros establecimientos públicos, i los tomará por un valor en tasación de los derechos expresados en el artículo anterior, i habiendo asceso por una ú otra parte se hará recíprocamente el abono.

$6^{\circ}$ El Gobierno prestará á la empresa todo el lleno de su proteccion removiendo todo obstáculo que pueda entorpecer, i si V.M. se digna asociar su nombre a una obra tan útil y gloriosa, permitirá que se titule: Excavación de María Cristina.

Si V. M. considera que por este medio puede el exponente contribuir al bien del país se servirá tener en consideración el proyecto expresado, a cuyo fin a V.M. suplica tenga a bien aprobar las proposiciones que preceden, mandando dar las órdenes convenientes a las autoridades á que corresponda para que dado lugar se ponga a la empresa en disposición de empezar sus trabajos, i desenterrar las preciosidades que yacen sin utilidad bajo las ruinas de la antigua Itálica. Así lo espera el esponente de Vuestra Real begninidad mientras ruega al cielo dilate su vida por muchos i felices años. Madrid, 11 de marzo de 1839. A L.R.P. de V.M. Domingo Ronchi.

Minuta de oficio en que se informa no debería
permitirse a Domingo Rochi la venta en el ex-
tranjero de los objetos de antigüedad que extra-
jese de Itálica, en el caso de que se le diese per-
miso para realizar excavaciones

Excmo. Señor:

Esta Acad $^{\mathrm{a}}$. de la Historia ha recibido la R. Orden de 18 de marzo próximo anterior en que se le manda informar sobre la exposición elevada por Domingo Rochi, el cual solicita se le permita hacer excavaciones en la antigua Itálica bajo ciertas bases que en ella propone, entre las cuales la más notable es la que se le dé facultad para poder exportar al extrangero las antigüedades de aquellas inmortales ruinas.

(...) La Cedula de 6 d julio de 1803, como ley, en la Nov. Recopilación, (...) en el reino bajo la custodia e inspección de la Academia y lo mismo confirmó en Real Orden de diciembre de 1818 , y en otra de 12 de agosto de 1827 , que se publicaran y mandara circular por el extinguido Consejo de Castilla, habiendo de antemano prevenido S.M. en 27 de abril del referido año de 1827, que el Asistente de Sevilla fuera el protector de los Monumentos de antigüedades de esta ciudad y sus contornos, sin perjuicio de la inspección general que en este ramo compete a la Academia de la Historia. El mismo Señor D. Fernando VII por real orden de $1^{\circ}$ de mayo de 1830 aprobó, la formación de un museo de antigüedades, si bien defirió su ejecución para tiempos de menos penuria; y la Reina Gobernadora en 18 de marzo de 1837, mando asimismo que la Academia manifestare si el local que ocupaba actualmente era susceptible de mayor ampliación para colocar cómodamente la biblioteca y los objetos de antigüedad, que poseía y no teniéndolo, indicara el edificio que pudiera destinárselo para que así se realizase. Por último en una Real Orden de 20 de agosto del año próximo pasado dispuso sabiamente S.M. que no pudiera sacarse fuera de España pinturas, antigüedades y otros objetos artísticos, con el laudable fin de que se guardasen entre nosotros no solo por el honor y gloria nacional, sino también por el grande auxilio que prestan a la ilustración de nuestra literatura y arte.

Tal es la legislación vigente en materia de antigüedades, cuyo espíritu y letra se dirige terminantemente a que se conserven con todo cuidado, y si que sirvan de ornato y utilidad de la nación, debiendo la Academia con sentimiento, que su estado actual de deterioro acusara la tibiesa y descuido del Gobierno si las estrecheces del erario y los graves trastornos de la guerra civil no le impidiese convertir su actuación a tan venerables monumentos. Pero a pesar de la situación lastimosa de nuestros días, cree la Academia que sería deshonroso permitir que se pusiesen a la venta los restos preciosos que quedan de los siglos pasados, y que por fortuna han resistido á los envates del tiempo (...). Aun cuando D. Domingo Ranchi quisiera hacer descubrimientos á su costa y formar un museo para instrucción de los anticuarios españoles, (...) manifiesta como principal objeto sacar fuera del país los fragmentos y reliquias de aquella célebre ciudad, i quiere no ser lo opuesto de semejante demanda con lo que con tanto acierto ordenaron los Sres. ReyesD. Carlos IV y Sr. Fernando VII 
(...) Bastante y bien sensibles pérdidas han sufrido por nuestro país en pinturas clásicas, en bellas esculturas, en libros sacros y preciosos monumentos que desde la guerra de la independencia acá han desaparecido de España, pero (...) por hallarse sepultado en el seno de la tierra, no han podido arrancarnos ni los ejércitos de $\mathrm{Na}$ poleón ni los comisionados de países extranjeros para decorar y ennoblecer sus gabinetes de historia natural. Personándose el Gobierno de que a nadie mejor que hacer que á él toca hacer excavaciones y formar un museo de antigüedades de un modo correspondiente a la dignidad de la Nación (...) le incumbe la obligación de mandar que nadie penetre en ellas excepto las personas instruidas a quienes mueva el amor a las ciencias y a las artes, poner guardianes que impidan toda extracción y en fin encargar a las autoridades el cumplimiento de lo que tantas veces se ha prevenido en esta materia. Este ha sido el clamor constante de la Academia desde que se les encomendó por S.M. la inspección de todas las antigüedades del Reino.

Resultando que con fecha 28 de marzo del año próximo el Gobernador Civil de Almería comunicó a este Ministerio que según le expresaba el Alcalde de Berja D. Antonio Oliver, estándose practicando excavaciones para extracción de tierras en la finca que en el paraje llamado Santa Muña de esta ciudad posee el vecino D. Gracián Villegas, había sido encontrado un sarcófago de mármol blanco de dos metros de longitud, al parecer de época antigua y en buen estado de conservación.

Resultando que la Comisión de Monumentos de Almería se dirigió a este Ministerio expresando que el sarcófago de que se trata lo considera romano-cristiano y que si las Reales Academias proponían su adquisición por el Estado se resolviese favorablemente antes que tan interesante testimonio del arte antiguo vaya a parar al extranjero. Resultando que la Real Academia de Bellas Artes de San Fernando propone la adquisición por el Estado y su depósito en el Museo Arqueológico Nacional del sarcófago de referencia.

Resultando que pasado el expediente a informe de la Junta Superior de Excavaciones y Antigüedades, esta docta entidad propuso se declarase ser propiedad del Estado el sarcófago de que se trata, ser el descubridor D. Gracián Villegas y se nombrase la Comisión que había de valorar el objeto encontrado.

De conformidad con la indicada propuesta de la Junta Superior de Excavaciones y Antigüedades, S.M. el Rey (q. D. g) ha tenido a bien disponer lo siguiente: $1^{\circ}$ De conformidad con los artículos $5^{\circ}$ de la Ley de

7 de julio de 1911 y el Reglamento de $1^{\circ}$ de marzo de 1912, ser declara ser propiedad del Estado al sarcófago de mármol blanco con relieves cuyas representaciones son asunto de la vida de J.C. de arte romano correspondiente al siglo IV de J.C. hallado casualmente al extraer tierras en una finca sita en el paraje denominado Santa Muña, término municipal de Berja (Almería), propiedad del vecino de dicha villa D. Gracián Villegas.

$2^{\circ}$ De acuerdo con lo que determina el artículo $5^{\circ}$ apartado $2^{\circ}$ de la citada Ley y el $6^{\circ}$ del Reglamento, al descubridor D. Gracián Villegas, recibirá al hacer entregas del sarcófago y como indemnización, la mitad del importe de la tasación legal del mismo.

$3^{\circ}$ Con arreglo al artículo $6^{\circ}$ de la Ley y 10 y 11 del Reglamento proceda encargar la valoración a una Comisión compuesta de tres señores académicos, uno de los cuales será designado por el particular expropiado.

$4^{\circ}$ Siendo atribución de la Junta Superior de Excavaciones proponer los individuos de la Academia que deben constituir en cada caso las Comisiones valoradotas, conforme al artículo 31 del Reglamento de $1^{\circ}$ de marzo de 1912 , se acepta lo que propone para tasar el sarcófago de mármol con relieves de arte romano hallado en Berja (Almería) y en su virtud se nombró al Sr D. Ramón Mélida, Académico de Número de las Reales Academias de la Historia y de Bellas Artes de San Fernando.

$5^{\circ}$ Se pone en conocimiento del descubridor y depositario del repetido sarcófago D. Gracián Villegas, el derecho que tiene a designar para que forme parte de la anterior Comisión tasadora, a uno de los Sres. Académicos de número de cualquiera de las Academias de la Historia y de Bellas Artes de San Fernando.

$6^{\circ}$ Se dar las gracias al Gobernador Civil de Almería y al Alcalde de Berja por el celo demostrado en la conservación y custodia de monumento, adoptando medidas para evitar su deterioro (...).

\section{Aplicación de la Ley de 1911 y el Reglamento de 1912.}

La adquisición de propiedad de los bienes arqueológicos de la Necrópolis Púnica de Eubusus por el Estado en virtud de una declaración de utilidad pública. 1916.

En el expediente incoado por virtud de las reclamaciones entabladas por D. Antonio Vives y Escudero y el Patronato del Museo Arqueológico de Ibiza, acerca del derecho exclusivo que respectivamente alegan tener para practicar excavaciones en la Necrópolis Púnica de Eubusus, que existe cerca de aquella ciudad en el lugar conocido por Puig des Mulins: 
Resultando que la Junta Superior de Excavaciones y Antigüedades, en vista del informe emitido por el catedrático D. Manuel Cazurro y Ruíz, como Delegado Director de dichas excavaciones, previa visita de inspección que el último realizó a las mismas, ha propuesto a este Ministerio:

$1^{\circ}$ Que se declare Monumento Nacional la expresada necrópolis, bajo la protección del Estado e inmediata inspección de la Comisión provincial de Monumentos Históricos Artísticos.

$2^{\circ}$ Que cuando se crea llegado el momento se incoe el expediente de utilidad pública que determina el artículo $4^{\circ}$ de la Ley de 7 de junio de 1911 y los $8^{\circ}$ y $9^{\circ}$ del Reglamento de $1^{\circ}$ de marzo de 1912 , vigentes en la materia, y en los que se prescribe que el Estado se reserva el derecho de hacer excavaciones en propiedades particulares, ya adquiriéndolas, ya indemnizando al propietario, pudiendo las ruinas, se encuentren bajo tierra o sobre el suelo, pasar a ser propiedad del Estado, previa la correspondiente indemnización al dueño del terreno, y al explorador, si existiere.

$3^{\text {o }}$ Que mientras se transmitan los expedientes que se incoen se suspendan las excavaciones legítimas o fraudulentas que allí puedan practicarse.

$4^{\circ} \mathrm{Y}$ que se den las gracias al Sr. Cazurro:

$1^{\circ}$. Considerando que dada la importancia excepcional que para la historia patria tiene la Necrópolis citada, por ser uno de los pocos yacimientos arqueológicos en que se encuentran de manifiesto los vestigios de la civilización púnica, se impone la intervención del Estado, en el asunto, a fin de evitar que tal Necrópolis se destruya, perdiéndose sus objetos para el Museo Arqueológico de Ibiza, acaso único en su género.

$2^{\circ}$. Considerando que sin perjuicio de llegarse en su día, si preciso fuera, a la declaración de monumento nacional respecto de dicha Necrópolis, basta hacer por ahora la de utilidad pública, a tenor de los textos citados, con la ocupación temporal subsiguiente prevista en el título III de la Ley de Expropiación Forzosa de 10 de enero de 1879, cuyo artículo 55 establece que la Administración, así como las Corporaciones o personas en quienes hayan subrogado sus derechos, podrán ocupar temporalmente los terrenos de propiedad particular en el caso de extracción de materiales de toda clase necesario para la ejecución de obras de utilidad pública que se hallen diseminados por la propiedad o hayan de ser objetos de una explotación formalmente organizada. $3^{\circ}$. Considerando que la solución anterior es tanto mas pertinente cuanto que la adquisición definitiva por el Estado de los terrenos en que la Necrópolis está enclavada produciría las consecuencias de que le fueran totalmente inútiles una vez terminadas las excavaciones, y en cambio la ocupación temporal no perjudicaría ningún derecho de propiedad o de excavación, puesto que aquellas personas o entidades que las ostente habrán de ser indemnizadas en forma lega.

\section{Adquisición por parte del Estado de un mosaico romano en Casariche (Sevilla).}

- Oficio por el que se comunica el descubrimiento de un mosaico romano por lo que se solicita permiso para hacer excavaciones.

Enterada esta Comisión de un descubrimiento arqueológico verificado en las inmediaciones de Casariche, acordó visitar el lugar del descubrimiento, como lo efectuó el día 16 del corriente, y en junta celebrada en el día de ayer acordó comunicar a V.E. lo siguiente. El descubrimiento arqueológico radica en la finca de D. Joaquín García Hidalgo, vecino de Puente Genil, y consiste en un interesante mosaico de la época de la dominación romana en nuestra patria. Mide diez y ocho metros cuadrados, cuya disposición y asunto pueden admirarse en las adjuntas fotografías, predominando en él los colores blanco, rojo, azul y negro, y en perfecto estado de conservación.

Esta Comisión vería con gusto que esa Real Academia de la que V.E. es dignísimo Presidente, solicitara del Ministro de Instrucción Pública y Bellas Artes, el crédito suficiente para hacer las excavaciones precisas para poder completar el descubrimiento, pues a juzgar por los restos de excavaciones que se conservan, serían de gran interés para la historia de la civilización romana en Andalucía.

Al propio tiempo como se trata de un precioso mosaico que merece ser conservado con esmero, y se encuentra casi a flor de tierra, esta Comisión propone a V.E. consiga las autorizaciones oportunas para evitar cualquier deterioro, y su pronto traslado a esta ciudad para colocarlo en lugar conveniente.

Sevilla, 19 de mayo de 1919.

- Oficio de la Dirección General de Bellas Artes al Presidente de la Junta Superior de Excavaciones y Antigüedades y de la Real Academia de la Historia sobre el mosaico romano hallado en Casariche en 1919.

Con esta fecha digo al Sr. Presidente de la Junta Superior de Excavaciones y Antigüedades lo siguiente: 
Excmo. Sr:

Con fecha de 23 de junio de 1919, se remitió a esa Junta Superior de Excavaciones en virtud de expediente incoado por este Ministerio, la instancia de la Real Academia de San Fernando, haciendo suyas las pretensiones formuladas por la Comisión provincial de Monumentos históricos de Sevilla, referentes al descubrimiento de un mosaico en Casariche, a fin de que la docta Corporación de su digna presidencia emitiese sobre el particular su autorizado informe, y con fecha 18 de febrero del corriente año la Real Academia de la Historia dice entre otros particulares lo siguiente: "que la Comisión de Monumentos de Sevilla en su Memoria dando cuenta de los trabajos efectuados expresa, que examinadas por la referida Comisión, los mosaicos descubiertos en Casariche, pudo comprobarse constituían un hermoso pavimento romano de diez y ocho metros cuadrados, en muy buen estado de conservación, perteneciente sin duda alguna casa de campo de las proximidades de la antigua población de Ventipo y según parece la preciosa pieza ha sido adquirida en la actualidad por persona de alta posición y trasladada a Madrid, y que la citada Real Academia lo comunica a la Superioridad a los efectos procedentes en derecho.

En su virtud, esta Dirección General al trasladar lo anteriormente expuesto a V.E. reitera la petición del informe que de esa Junta de Excavaciones solicitó en la fecha expresada a los efectos oportunos".

Madrid, 12 de marzo de 1925.

- Oficio al Presidente del Directorio Militar para que vuelva el mosaico romano de Casariche a propiedad del Estado y sea trasladado al Museo Arqueológico

La Comisión de Monumentos Históricos y Artísticos de la Provincia de Sevilla, ha visto con sorpresa y dolor que el valioso mosaico romano descubierto casualmente en el pueblo de Casariche (Sevilla), propiedad del Estado, ha sido arrancado del lugar del descubrimiento, y sin conocimiento de las autoridades, se ha dispuesto de él como de cosa propia por un particular y trasladado a Madrid, con evidente transgresión de las disposiciones legales vigentes.

A raíz del hallazgo la Comisión de Monumentos solicitó de la Superioridad, que dicho mosaico, dado su valor e interés artístico se trasladase al Museo de Sevilla, y la Real Academia de San Fernando, hizo suyos los deseos de la Comisión de Monumentos, elevándose a la Junta Superior de Excavaciones el oportuno expediente incoado por el Ministerio de Instrucción Pública y Bellas Artes. Recientemente en 22 de febrero de 1926, Don Santiago Montoto, Académico correspondiente de las Reales de la Historia y de Bellas Artes de
San Fernando, acudió al Gobernador Civil de la Provincia, denunciando que el mosaico descubierto en Casariche, había sido arrancado y trasladado a Madrid, infrigiéndose la Ley de Excavaciones en su artículo 5, que dispone que las antigüedades descubiertas casualmente en el subsuelo son propiedad del Estado. En virtud de la anterior denuncia, el Gobernador mandó formar expediente para averiguar los hechos, a cuyo fin envió al delegado Gobernativo de Estepa su trasladado de la demanda presentada.

El alcalde de Casariche, en cuyo término municipal fue descubierto el mosaico, tomó declaración a varias personas, después de lo cual se vino en conocimiento que el propietario del terreno donde casualmente fue descubierto el mosaico, don Joaquín García Hidalgo, había dispuesto de él y abrogándose facultades que no tenía, lo entregó al Duque del Infantado, quien lo tiene en el castillo de Viñuelas. Enterada la Real Academia de la Historia de la desaparición de dicha obra de arte por la Memoria recientemente publicada por la Comisión de Monumentos, se dirigió en 18 de febrero del corriente año al Ministerio de Instrucción Pública y Bellas Artes poniéndolo en su conocimiento a los efectos precedentes en derechos.

Expuestos los anteriores antecedentes, esta Comisión de Monumentos solicita una vez conocidos los nombres del individuo que dispone del mosaico y su actual paradero; que por V.E. se ordena vuelva a la propiedad del Estado y al tesoro de la nación tan valiosa obra arqueológica, siendo depositada en Sevilla donde tanto testimonios se guardan del arte romano en nuestra patria.

Lo que confiadamente espero dado el alto espíritu de justicia que anima los actos del Gobierno que V.E. preside.

\section{BIBLIOGRAFÍA}

ALEGRE ÁVILA, J. M. (1994): Evolución y régimen jurídico del patrimonio histórico. Ministerio de Cultura, Madrid.

- (1997): "El Patrimonio Arqueológico: aspectos de su régimen jurídico", Patrimonio Cultural y Derecho 1: 121-130.

ÁLVAREZ ÁLVAREZ, J.L. (1989): Estudios sobre el Patrimonio Histórico Español y la Ley de 25 de junio de 1985. Civitas, Madrid.

ALVAREZ GENDIN, S. (1977): El dominio público de las cosas de arte y científicos, Editorial Moneda y Crédito, Madrid.

AMORES, F.; BELTRÁN, J. y FERNÁNDEZ LACOMBA, J. (2008): El rescate de la Antigüedad 
Clásica en Andalucía, Fundación Focus Abengoa, Sevilla.

BALLART HERNÁNDEZ, J. (1997): El patrimonio histórico y arqueológico: valor y uso. Barcelona.

BARRERO RODRÍGUEZ, C. (1990): La ordenación jurídica del Patrimonio Histórico. Universidad de Sevilla, Sevilla.

BERLANGA PALOMO, Ma J. (2005): Arqueología y erudición en Málaga durante el siglo XIX, Universidad de Málaga, Málaga.

GARCÍA DE ENTERRÍA, E. (1983): “Consideraciones sobre una nueva legislación del patrimonio artístico, histórico y cultural", Revista Española de Administraciones Públicas 39: 576-580.

GONZÁLEZ-UBEDA RICO, G. (1981): Aspectos jurídicos de la protección del patrimonio históricoartístico y cultural. Ministerio de Cultura, Madrid.

MAIER ALLENDE, J. (2003): "II Centenario de la Real Cédula. La Real Academia de la Historia y el inicio de la legislación sobre el Patrimonio Arqueológico y Monumental de España”, Boletín de la Real Academia de la Historia CC: 439-473.

- (2008): Noticias de antigüedades de las actas de sesiones de la Real Academia de la Historia (18341874), Real Academia de la Historia, Madrid.
MOREU BALLONGA, J.L. (1980): Ocupación, hallazgos y tesoros, Bosch, Barcelona.

- (1993): "Hallazgo de interés histórico, artístico y/o arqueológico" en Revista de Administración Pública 132: 171-208.

PÉREZ-JUEZ GIL, A. (2006): Gestión del Patrimonio Arqueológico. Editorial Ariel, Barcelona.

ROMA VALDÉS, A. (2008): La aplicación de los delitos sobre el patrimonio cultural. Estudios de derecho penal y criminología, Editorial Comares, Granada.

SALAS ALVAREZ, J. de la A. (2005): La recuperación del patrimonio Arqueológico de Andalucía durante la Ilustración (1736-1808). Tesis Doctoral, Universidad de Sevilla.

YAÑEZ VEGA, A. (1997): "Estudio sobre la Ley de Excavaciones y Antigüedades de 1911 y el Reglamento para su aplicación de 1912", en La cristalización del pasado: génesis y desarrollo del marco institucional de la arqueología en España. Universidad de Málaga.

YÁÑEZ, A. y LAVÍN, A. C. (1999): “La legislación española en materia de Arqueología hasta 1912: análisis y evolución de su contexto", Patrimonio Cultural y Derecho 3: 123-146.

FeCha de ENTRADA: 9-02-2010

FECHA DE ACEPTACIÓN: 12-03-2010 